\title{
SLC26A6 wt Allele
}

National Cancer Institute

\section{Source}

National Cancer Institute. SLC26A6 wt Allele. NCI Thesaurus. Code C114428.

Human SLC26A6 wild-type allele is located in the vicinity of 3p21.3 and is approximately $10 \mathrm{~kb}$ in length. This allele, which encodes solute carrier family 26 member 6 protein, plays a role in the modulation of chloride transport. 